\title{
Article \\ Physical Activity and Prevalence of Depression and Antidepressants in the Spanish Population
}

\author{
Carmen Galán-Arroyo ${ }^{1}\left(\mathbb{D}\right.$, Damián Pereira-Payo ${ }^{2}{ }^{\oplus}$, Jorge Rojo-Ramos ${ }^{3}\left(\mathbb{D}\right.$, Miguel A. Hernández-Mocholí ${ }^{4}$,

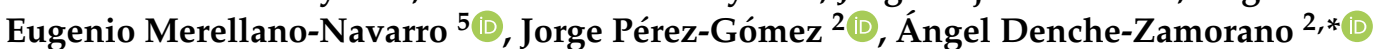 \\ and Jose Carmelo Adsuar ${ }^{1}$ (i)
}

Citation: Galán-Arroyo, C.;

Pereira-Payo, D.; Rojo-Ramos, J.;

Hernández-Mocholí, M.A.;

Merellano-Navarro, E.; Pérez-Gómez, J.; Denche-Zamorano, Á.; Adsuar, J.C. Physical Activity and Prevalence of Depression and Antidepressants in the Spanish Population. Healthcare 2022, 10, 363. https://doi.org/ $10.3390 /$ healthcare 10020363

Academic Editors: Jennifer R. Pharr and Kavita Batra

Received: 24 December 2021

Accepted: 9 February 2022

Published: 12 February 2022

Publisher's Note: MDPI stays neutral with regard to jurisdictional claims in published maps and institutional affiliations.

Copyright: (C) 2022 by the authors. Licensee MDPI, Basel, Switzerland. This article is an open access article distributed under the terms and conditions of the Creative Commons Attribution (CC BY) license (https:// creativecommons.org/licenses/by/ $4.0 /)$.
1 Promoting a Healthy Society Research Group (PHeSO), Faculty of Sport Sciences, University of Extremadura, 10003 Caceres, Spain; magaar04@alumnos.unex.es (C.G.-A.); jadssal@unex.es (J.C.A.)

2 Health Economy Motricity and Education (HEME), Faculty of Sport Science, University of Extremadura, 10003 Caceres, Spain; dpereirab@alumnos.unex.es (D.P.-P.); jorgepg100@unex.es (J.P.-G.)

3 Social Impact and Innovation in Health (InHEALTH), University of Extremadura, 10003 Caceres, Spain; jorgerr@unex.es

4 Physical Activity and Quality of Life Research Group (AFYCAV), Faculty of Sport Science, University of Extremadura, 10003 Caceres, Spain; mhmocholi@unex.es

5 Grupo de Investigación EFISAL, Universidad Autónoma de Chile, Talca 3460000, Chile; emerellano@gmail.com

* Correspondence: andeza04@alumnos.unex.es

\begin{abstract}
Introduction: Depression is a mental disorder that affects more than 250 million people in the world, limiting their functional capacities. The work of public health policies is aimed at reducing its prevalence as well as its pharmaceutical cost. Physical activity (PA) programs are interventions with a high potential for effectiveness. Objectives: To establish the relationships between physical activity and the prevalence of depression and antidepressant intake in the Spanish population. Design: We performed a correlational study that was based on data from the European Health Survey Spain 2020 with 20,287 participants, aged 18-84 years, living in Spain. Results: Dependency relationships were found between the prevalence of depression, and: the frequency of PA, the number of days of PA per week, and the number of days of muscle strengthening in the population, in both sexes, and in all age groups $(p<0.001)$. Dependency relationships were found between the three PA variables and the prevalence of taking antidepressants $(p<0.001)$. An elevated prevalence of depression and antidepressant taking were found in the inactive groups compared to those who performed PA $(p<0.05)$. Conclusions: There is an inverse relationship between physical activity and the probability of suffering from depression and the intake of antidepressants. Performing PA 3-4 days/week, including 1-2 days of strength work, could be the best proposal to reduce the prevalence of depression in the Spanish population.
\end{abstract}

Keywords: health; depression; physical activity; antidepressants; strength

\section{Introduction}

Depression is currently the most prevalent mental disorder [1] and is characterized by profound sadness and loss of interest as well as a wide range of emotional, cognitive, physical and behavioral symptoms [2].

Depression is a major contributor to the global burden of disease [3], causing a substantial burden on health systems [4]. At its most extreme, it can lead to suicide [3]. Public health policies focus their efforts on preventing this disorder, which affects one in ten people in the world [1], $6.4 \%$ of Europeans [5] and 6.68\% of Spanish [6]. There is a need to scale up strategies on early interventions [7], because treatments with antidepressants are not only costly but also unsuccessful [8]. This is done through health promotion campaigns, advice on good practices, etc. [1]. Health promotion through physical activity and exercise programs for adults is an intervention with a proven beneficial effect on reducing the risk of depression [1]. 
It is universally accepted that regular physical activity is one of the priorities in Public Health as a means of preventing chronic diseases [9] and the decrease in premature mortality [10]. By physical activity we mean any bodily movement that is produced by skeletal muscles that produces an energy expenditure that is greater than that at rest [11]. Regular physical activity improves both physical and mental health [12]. Closely linked to physical activity and Public Health is physical exercise, which is defined as planned, structured, and repeated physical activity that is aimed at acquiring, maintaining, or improving physical fitness [11]. In relation to PA and PE we can find strength work, which is physical ability to perform work or a movement, being one of the essential performance factors [13]. Muscle strengthening is closely related to health [14].

When it comes to depression, PA is an effective preventive tool against depressive disorders [15] and has a positive effect on physical and mental health due to the release of endorphins, reducing anxiety, depression, and stress [12].

There is a large body of evidence on the benefits of PA and PE for people with depression, in prevention [16,17] as a protective factor against depression [18], as a preventive strategy [19], effective in primary prevention [20], and treatment [21-25], and as an adjuvant treatment $[19,26,27]$ from severe to moderate depression with an exercise program [28], where strengthening exercises [28] could reduce the intake of antidepressants [16,17]. There were two meta-analyses of structured exercise programs that were recently published that conclude that heart rate and muscle strength improvement (based on resistance exercise) are moderators of depression improvement in middle-aged and older adults [29,30]. However, there is a lack of documentation on the recommended frequency of physical activity depending on the type of exercise that is performed (aerobic and/or strength) to prevent or reduce the prevalence of depression and to establish strategies for different age groups.

The aim of this study is, therefore, to establish relationships between physical activity and the prevalence of depression and antidepressant intake in the Spanish population, and to be able to establish a recommended dose of physical exercise to prevent and reduce depression.

\section{Materials and Methods}

\subsection{Study Design}

In this cross-sectional investigation, a descriptive correlational study was performed that was based on data that were obtained from the public files included from the European Health Interview Survey of Spain 2020 (EESE 2020). The EESE is a survey that is conducted every five years by the Ministry of Health and the Spanish National Institute of Statistics (INE), forming part of the European Health Interview Survey (EHIS). This survey is coordinated by Eurostat and is regulated by Regulation (EC) 1338/2008 and Commission Regulation 141/2013. The interviews were conducted between 15 July 2019 to 24 July 2020 by previously trained and accredited interviewers.

\subsection{Participants}

The initial sample constituted of 22,072 participants, aged between 15 and 104, residing in Spain, who were interviewed on the occasion of the EESE 2020, individual adult questionnaire. For this study, data from people aged between 18 and 85 years were taken into account, so that those over 85 years of age (1282 participants) and those under 18 (503 participants) were excluded. The final sample was 20,287 persons: 9731 men and 10,556 women.

The participants were selected using a three-stage sampling system with stratification: census sections (first stage units, municipalities were grouped into seven strata, according to number of inhabitants, selecting the sections in each stratum, taking into account the probability proportional to its size, according to the main family dwellings belonging to it), main family dwellings (second stage units, selecting living with equal probability, through systematic sampling with random start), and surveyable persons (third stage units, one person per dwelling, using the Kish random method. The selection is random, with equal probability for each adult in the dwelling). 


\subsection{Ethics}

Not required, since the data were obtained from anonymous, non-confidential public files.

\subsection{Variables and Procedures}

The variables that were used from EESE 2020 and the procedures that were followed with these variables are shown in the following table (Table 1).

Table 1. Variables and definitions.

\begin{tabular}{|c|c|}
\hline Variable & Definition of Variable \\
\hline Gender & Male or female. \\
\hline Age & In years. \\
\hline Age group & Youth (18-34 years); Young adults (35-49 years); Older adults (50-64 years); Older (65-84 years). \\
\hline Life Depression & $\begin{array}{l}\text { Item p.25_20a: "Have you ever suffered from depression?" Yes (Depression). No (No depression). For the analyses } \\
\text { that included this variable, } 19 \text { participants with responses, Don't know, or No answer (NS/NC) were excluded. }\end{array}$ \\
\hline Depression 12 months & $\begin{array}{l}\text { Item p.25_20b: "Have you suffered from it in the last } 12 \text { months?" Yes (Depression). No (No depression). For } \\
\text { analyses including this variable, } 22 \text { participants with responses, NS/NC. }\end{array}$ \\
\hline Diagnosed Depression & $\begin{array}{l}\text { Item p.25_20c: "Has a doctor told you that you have it?" Yes (Depression). No (No depression). For analyses that } \\
\text { included this variable, } 21 \text { participants with "NS/NC" responses were excluded. }\end{array}$ \\
\hline Antidepressants & $\begin{array}{l}\text { From items: Q.85: "During the past } 2 \text { weeks, have you taken any medication that was prescribed to you by a } \\
\text { physician?" Yes/No; Q86: "During the past } 2 \text { weeks, have you taken any medications, including herbal medications } \\
\text { or vitamins, that were not prescribed to you by a doctor?" Yes/No; Q87_14a: "Next, I am going to read you a list of } \\
\text { types of medications, please tell me which one(s) of them you have taken in the last } 2 \text { weeks_antidepressants, } \\
\text { stimulants?" Yes/No. Antidepressants (Participants with affirmative answers to items p.87_14a); Non-depressants } \\
\text { (participants with "No" in items: p.85 and p.86; or with these, "Yes", if p.87_14a = "No"). }\end{array}$ \\
\hline Frequency of PA & $\begin{array}{l}\text { From item p.112: "Which of these possibilities best describes the frequency with which you do some physical } \\
\text { activity in your free time?" Never ("I do not exercise. I spend my free time almost completely sedentary"); Occasional ("I } \\
\text { do some occasional physical or sport activity"), Several a month ("I do physical activity several times a month"); Several a } \\
\text { week ("I do sport or physical training several times a week"). }\end{array}$ \\
\hline PA days & $\begin{array}{l}\text { From item p.117: "How many days do you practice sport, gymnastics, cycling, fast walking, etc., at least } 10 \text { min in a } \\
\text { row?". Groups were created: } 0 \text { days/week, 1-2 days/week, 3-4 days/week and 5+ days/week. }\end{array}$ \\
\hline Muscle strengthening days & $\begin{array}{l}\text { From item p.119: "How many days do you do activities specifically aimed at strengthening your muscles?" Groups } \\
\text { were created: } 0 \text { days/week, 1-2 days/week, 3-4 days/week and 5+ days/week. }\end{array}$ \\
\hline
\end{tabular}

\subsection{Statistical Analysis}

The data analysis was carried out with the IBM SPSS Statistics v.25 statistical analysis software.

Initially, the distribution that was followed by the data of the study variables was checked by performing a Kolgomorov-Smirnov test. When insufficient evidence was found to assume the normality of the variable distributions, it was accepted that the data did not follow a normal distribution for subsequent analyses. For this reason, in the descriptive analysis to characterize the sample, the median, the interquartile range (continuous variables), and the absolute and relative frequencies (ordinal variables) were used to present the data of the different groupings that were formed. Similarly, for this reason, nonparametric statistical tests were used to evaluate the possible intergroup differences using the Mann-Whitney U test (for the continuous variable: age). The chi-square statistic (to analyze possible dependency relationships), and a pairwise z-test for independent proportions, using the Bonferroni correction when it was necessary, (to analyze possible differences between proportions presented by sexes) were used for the categorical variables: age group, lifetime depression, 12-month depression, diagnosed depression, frequency of PA, days of PA, and days of muscle strengthening. The effect size was presented with Cramer's V o phi as necessary.

The level of significance that was established in this investigation was less than 0.05 .

\section{Results}

The median age of the population that was studied was 54 years, being lower in men (53) than in women (55), with significant differences between the two $(p<0.001)$. Similarly, dependency relationships were found between the age group and $\operatorname{sex}\left(x^{2}=57.97, p<0.001\right.$, 
$V=0.053)$, with women presenting a higher proportion of the population than men in the elderly group (Table 2).

Table 2. Sociodemographic characteristics: age, age group, prevalence of depression and of taking antidepressants and physical activity; of the Spanish population aged 18-84 years in the EESE 2020.

\begin{tabular}{|c|c|c|c|c|c|c|c|}
\hline Variables & & & & & & & \\
\hline Ages (Years) & Total $=20,287$ & Men $n=9731$ & Women $n=10,556$ & - & - & $p$ & - \\
\hline Median (RI) & $54(26)$ & $53(24)$ & $55(27)$ & - & - & $<0.001$ & - \\
\hline Median (DE) & $53.4(16.8)$ & $52.7(16.5)$ & $54.1(17.0)$ & - & - & - & - \\
\hline Age (Years) & Total $=20,287$ & Men $n=9731$ & Women $n=10,556$ & $x^{2}$ & $d f$ & $p^{*}$ & $V$ \\
\hline Young people & $2913(14.4)$ & 1409 (14.5) & $1504(14.2)$ & \multirow{4}{*}{58.0} & \multirow{4}{*}{4} & \multirow{4}{*}{$<0.001$} & \multirow{4}{*}{0.053} \\
\hline Young adults & $5647(27.8)$ & $2841(29.2)$ & $2806(26.6)$ & & & & \\
\hline Older adults & $5842(28.8)$ & $2881(29.6)$ & $2961(28.1)$ & & & & \\
\hline Older & $5885(29.5)$ & $2600(26.7) \mathrm{a}$ & $3285(31.1) b$ & & & & \\
\hline Depression Life & Total $=20,268$ & Men $n=9726$ & Women $n=10,542$ & $x^{2}$ & $d f$ & $p^{*}$ & $\Phi$ \\
\hline Depression & $1922(9.5)$ & $603(6.2) \mathrm{a}$ & $1319(12.5) b$ & \multirow{2}{*}{234.8} & \multirow{2}{*}{1} & \multirow{2}{*}{$<0.001$} & \multirow{2}{*}{0.108} \\
\hline No depression & $18,346(90.5)$ & $9123(93.8) \mathrm{a}$ & $9223(87.5) b$ & & & & \\
\hline Depression 12 months & Total $=20,265$ & Me $n n=9725$ & Women $n=10,540$ & $x^{2}$ & $d f$ & $p^{*}$ & $\Phi$ \\
\hline Depression & $1411(7.0)$ & $429(4.4) \mathrm{a}$ & $982(9.3) b$ & \multirow{2}{*}{187.90} & \multirow{2}{*}{1} & \multirow{2}{*}{$<0.001$} & \multirow{2}{*}{0.096} \\
\hline No depression & $18,854(93.0)$ & 9296 (95.6) a & $9558(90.7) \mathrm{b}$ & & & & \\
\hline Diagnosed Depression & Total $=20,266$ & Men $n=9725$ & Women $n=10,541$ & $x^{2}$ & $d f$ & $p^{*}$ & $\Phi$ \\
\hline Depression & $1750(8.6)$ & $534(5.5)$ a & $1216(11.5) b$ & \multirow{2}{*}{234.28} & \multirow{2}{*}{1} & \multirow{2}{*}{$<0.001$} & \multirow{2}{*}{0.108} \\
\hline No depression & $18,516(91.4)$ & $9191(94.5) b$ & $9325(88.5) b$ & & & & \\
\hline Antidepressants & Total $=20,280$ & Men $n=9727$ & Women $n=10,553$ & $x^{2}$ & $d f$ & $p^{*}$ & $\Phi$ \\
\hline Antidepressants & $1116(5.5)$ & $302(3.1) \mathrm{a}$ & $814(7.7) \mathrm{b}$ & \multirow{2}{*}{206.74} & \multirow{2}{*}{1} & \multirow{2}{*}{$<0.001$} & \multirow{2}{*}{0.101} \\
\hline No antidepressants & $19,164(94.5)$ & 9425 (96.9) a & $9739(92.3) b$ & & & & \\
\hline Frequency of PA & Total $=20,269$ & Men $n=9722$ & Women $n=10,547$ & $x^{2}$ & $d f$ & $p^{*}$ & $V$ \\
\hline Never & $7168(35.4)$ & $3124(32.1) \mathrm{a}$ & $4044(38.3) b$ & \multirow{4}{*}{144.17} & \multirow{4}{*}{3} & \multirow{4}{*}{$<0.001$} & \multirow{4}{*}{0.084} \\
\hline Occasionally & 7955 (39.2) & $3793(39.0) \mathrm{a}$ & $4162(39.5) a$ & & & & \\
\hline Several per month & $2134(10.5)$ & $1151(11.8) \mathrm{a}$ & $983(9.3) \mathrm{b}$ & & & & \\
\hline Several per week & $3012(14.9)$ & $1654(17.0) \mathrm{a}$ & $1358(12.9) \mathrm{b}$ & & & & \\
\hline Days of PA & Total $=20,163$ & Men $n=9673$ & Women $n=10,490$ & $x^{2}$ & $d f$ & $p^{*}$ & $V$ \\
\hline 0 days/week & $10,412(51.6)$ & 4725 (48.8) a & 5687 (54.2) b & \multirow{4}{*}{82.96} & \multirow{4}{*}{3} & \multirow{4}{*}{$<0.001$} & \\
\hline 1-2 days/week & $2508(12.4)$ & 1175 (12.1) a & 1333 (12.7) a & & & & 0064 \\
\hline 3-4 days/week & $3426(17.0)$ & $1740(18.0) \mathrm{a}$ & $1686(16.1) b$ & & & & \\
\hline 5+ days/week & 3817 (18.9) & $2033(21.0) \mathrm{a}$ & $1784(17.0) \mathrm{b}$ & & & & \\
\hline Strengthening days & Total $=20,104$ & Men $n=9642$ & Women $n=10,462$ & $x^{2}$ & $d f$ & $p^{*}$ & $V$ \\
\hline 0 days/week & $16,452(81.8)$ & 7673 (79.6) a & $8779(83.9) b$ & & & & \\
\hline 1-2 days/week & $1467(7.3)$ & $681(7.1) \mathrm{a}$ & $786(7.5) \mathrm{a}$ & 118.97 & 3 & $<0.001$ & 0.077 \\
\hline 3-4 days/week & $1391(6.9)$ & $813(8.4)$ a & $578(5.5) \mathrm{b}$ & & & & \\
\hline 5+ days/week & $794(3.9)$ & $475(4.9) \mathrm{a}$ & $319(3.0) \mathrm{b}$ & & & & \\
\hline & $\begin{array}{l}p \text { ( } p \text {-value. } \\
\text { RI (Interqu } \\
\text { (ordinal va } \\
\text { nosed); An } \\
\text { antidepress } \\
\text { with which } \\
\text { gymnastic } \\
\text { do activiti } \\
\text { differences }\end{array}$ & $\begin{array}{l}\text { ann-Whitney U); } \\
\text { ile range); SD (St } \\
\text { bles); Depression } \\
\text { epressants (have t } \\
\text { ts in the last two } \\
\text { u do some physic } \\
\text { ycling, brisk walk } \\
\text { pecifically aimed } \\
\text { tween column pro }\end{array}$ & $\begin{array}{l}\text { ( } p \text {-value. Chi square } \\
\text { dard deviation); The d } \\
\text { Depression diagnosed } \\
\text { en antidepressants in th } \\
\text { eks); Frequency of PA (“" } \\
\text { activity in your free tin } \\
\text { g, etc., at least } 10 \text { min a } \\
\text { tstrengthening your m } \\
\text { ortions at } 95 \%) \text {. }\end{array}$ & $\begin{array}{l}\text { stic); } d f(\mathrm{c} \\
\text { are prese } \\
\text { a physicia } \\
\text { ast two w } \\
\text { ich of the } \\
\text { "'); Days I } \\
\text { time); Stre } \\
\text { cles); ab (l }\end{array}$ & $\begin{array}{l}\text { e fre } \\
\text { by al } \\
\text { Jon-d } \\
\text {; No } \\
\text { ssibil } \\
\text { ow } m \\
\text { lenin } \\
\text { subs }\end{array}$ & $\begin{array}{l}\text { ); } \Phi \text { (phi) } \\
\text { te and rel } \\
\text { ssion (De } \\
\text { epressant } \\
\text { est descri } \\
\text { days do y } \\
\text { s (how m } \\
\text { correspor }\end{array}$ & $\begin{array}{l}\text { Cramer's } \\
\text { frequenc } \\
\text { ion no di } \\
\text { ve not tak } \\
\text { ne frequer } \\
\text { actice sp } \\
\text { days do y } \\
\text { o significe }\end{array}$ \\
\hline
\end{tabular}


The prevalence of depression that was suffered at some time in life was $9.5 \%$ in the general population. Dependence relationships were found between the prevalence of depression and sex $\left(x^{2}=234.80, p<0.001, \Phi=0.108\right)$, with women $(12.5 \%)$ having a higher prevalence than men $(6.2 \%)$, with significant differences between them $(p<0.05)$. Similar results were found in the prevalence of depression in the last 12 months (7.0\%) and diagnosed by a physician $(8.6 \%)$ in the general population, with dependence relationships between the prevalence and the sex of the participants $\left(x^{2}=187.90, p<0.001, \Phi=0.096\right.$ and $x^{2}=234.28, p<0.001, \Phi=0.108$, respectively). In both, significant differences were found between the sexes $(p<0.05)$, with 6 and 4.6 percentage points of difference between the men and the women, with higher prevalence in women, both in depression at 12 months, as well as in diagnosed depression. These dependency relationships were also found between the prevalence of antidepressant use and $\operatorname{sex}\left(x^{2}=206.74, p<0.001, \Phi=0.101\right)$. The prevalence of taking antidepressants in the general population was $5.5 \%$, being more than twice as high in women $(7.7 \%)$ than in men $(3.1 \%)$, with statistically significant differences in prevalence $(p<0.05)$ (Table 2$)$.

A total of $74.6 \%$ of the general population reported not doing PA on a regular frequency: never (35.4\%) and occasionally (39.2\%). Dependency relationships were found between the frequency of PA and $\operatorname{sex}\left(x^{2}=144.17, p<0.001, V=0.084\right)$, the proportion of inactive women $(38.3 \%)$ was 5.2 percentage points higher than that of men $(33.1 \%)$, and the difference between the proportions of people with a frequency of several times a month or more between men $(28.8 \%)$ and women $(22.2 \%)$ was 6.6 points; all of these differences were significant $(p<0.05)$. Dependency relationships were also found between the days of PA per week and sex $\left(x^{2}=82.96, p<0.001, V=0.064\right)$. A total of $51.6 \%$ of the population reported performing PA zero days a week, this proportion being higher in women (54.7\%) than in men $(48.8 \%)$, with significant differences between the two $(p<0.05)$. Something that was also found in the proportions of people with $5+$ days of PA, being $18.9 \%$ in the general population, and finding a difference of 4 percentage points between men (21\%) and women (17\%). Much higher were the proportions of people who reported not performing muscle-strengthening exercises on any day of the week. In this sense, $81.8 \%$ of the general population performed these activities on zero days, and there was a relationship of dependence between these activities and $\operatorname{sex}\left(x^{2}=118.97, p<0.001, V=0.077\right)$. In women, this prevalence reached $83.9 \%$ compared to $79.6 \%$ in men, with $p<0.05$ (Table 2 ).

Dependency relationships were found between the lifetime prevalence of depression and the frequency of PA, both in the general population $\left(x^{2}=235.15, p<0.001, V=0.108\right)$ and in both sexes (Men: $x^{2}=76.73, p<0.001, V=0.089$; Women: $x^{2}=126.85, p<0.001$, $V=0.110$ ). The prevalence of lifetime depression was $13.4 \%$ in the inactive general population, being 4.8 percentage points lower in the population that performed PA occasionally $(8.6 \%)$ and about 8 points lower in the more active groups $(5.2 \%$ in the group that performed PA several times a month and 5.5\% in the group that performed PA several times a week), finding significant differences between the groups $(p<0.05)$. The same occurred in men and women, with significant differences between the prevalence of inactive and occasional people, and between these and the higher levels $(p<0.05)$. In women, the highest prevalence of lifetime depression was found in inactive women $(16.7 \%)$, with women who performed PA several times a month having the lowest prevalence $(7.1 \%)$. This was similar for men, with the lowest prevalence found among men who performed PA several times a month (3.6\%). These dependency relationships, both in the general population and in both sexes, were found in the prevalence of depression in the last 12 months and of diagnosed depression. Thus, significant differences were also found between the prevalence of depression among the different PA groups, being higher in the inactive than in the occasional, and in both groups and higher PA levels, with $p<0.05$. On the other hand, the prevalence of taking antidepressants showed dependence relationships with the frequency of PA, both in the general population $\left(x^{2}=198.95, p<0.001, V=0.099\right)$ and in both sexes (Men: $x^{2}=72.52$, $p<0.001, V=0.086$; Women: $\left.x^{2}=102.33, p<0.001, V=0.099\right)$. The prevalence in the inactive population was more than three times higher than the prevalence in the group with the 
highest frequency of PA (8.2\% vs. 2.5), with significant differences in proportions between these groups $(p<0.05)$. This finding in the general population also occurred in both men and women. Men who performed PA several times a month had the lowest prevalence of taking antidepressants $(1.3 \%)$, while the highest prevalence was found in inactive men (5.1\%). On the other hand, inactive women had a prevalence that was 6.9 points higher than women with the highest frequency of PA (10.7\% vs. 3.8) (Table 3).

The prevalence of lifetime, past 12 months, and physician-diagnosed depression also presented dependence relationships with the days of PA that were performed per week, both in the general population and in both sexes. The highest prevalence in the three depression conditions were in the groups that performed zero days of PA per week compared to the groups that performed PA, at least one day, with $p<0.05$; this was found in the general population, in men and in women. The lowest prevalence was found in the groups that performed PA between three and four days a week, with significant differences, in most cases, with respect to the prevalence of the other groups $(p<0.05)$. The highest prevalence was found in the inactive women: lifetime depression (15.7\%), 12-month depression $(12.1 \%)$, and diagnosed depression $(14.5 \%)$; with differences in proportions between 6-7 points with respect to the women who performed PA three to four days a week (lifetime: 7.8\%; 12-months: 5.3\%; diagnosed: 7.1\%) who presented the lowest prevalence. With smaller differences in proportions, the same was found in men, who presented differences of around 4-5 points between inactive and men with PA three to four days a week. These dependency relationships and these differences between the PA groups were also found in the prevalence of taking antidepressants, with prevalence that doubled or even tripled between inactive persons and those who took PA three to four days a week (Table 4).

The existence of dependency relationships between the prevalence of the three conditions of depression that were analyzed in this study and the number of days per week that muscle-strengthening activities were also found, both in the general population and in both sexes. In men, significant differences were found between the prevalence of depression of those who did not perform, at least one day a week, muscle strengthening exercises, compared to the rest of the groups, although no differences were found between the rest of the groups among themselves $(p<0.05)$. In women, the lowest prevalence of depression in the three conditions was found in those who performed these activities one to two days a week. Finally, dependency relationships were also found between the prevalence of taking antidepressants and the days per week that muscle strengthening exercises were performed, finding significant differences between those who did not perform, at least one day, and the rest $(p<0.05)$ in the general population (Table 5). 
Table 3. Relationship between the prevalence of: depression (lifetime, in the last 12 years and diagnosed); consumption of antidepressants; and frequency of physical activity (T112) in the general Spanish population of the EESE 2020 between 18 and 84 years, and by sex.

\begin{tabular}{|c|c|c|c|c|c|c|c|c|c|c|}
\hline \multicolumn{11}{|c|}{ Frequency of Physical Activity } \\
\hline Sex & Depression throughout Life & Total & Never & Occasional & Several/Month & Several/Week & $x^{2}$ & $d f$ & $p^{*}$ & V \\
\hline \multirow{2}{*}{ Men $(n=9717)$} & Depression & $603(6.2)$ & $284(9.1)$ a & $215(5.7) \mathrm{b}$ & $41(3.6) \mathrm{c}$ & $63(3.8) \mathrm{c}$ & \multirow{2}{*}{76.73} & \multirow{2}{*}{3} & \multirow{2}{*}{$<0.001$} & \multirow{2}{*}{0.085} \\
\hline & No depression & $9114(93.8)$ & $2828(90.9)$ a & $3578(94.3) \mathrm{b}$ & $1108(96.4) \mathrm{c}$ & $1590(96.2) \mathrm{c}$ & & & & \\
\hline Women $(n=10,535)$ & No depression & $9220(87.5)$ & $3367(83.3)$ a & $3688(88.7) \mathrm{b}$ & $912(92.9) \mathrm{c}$ & $1253(13.6) \mathrm{c}$ & 126.85 & 3 & $<0.001$ & 0.110 \\
\hline \multirow{2}{*}{ Total $(n=20,252)$} & Depression & $1918(9.5)$ & $958(13.4) \mathrm{a}$ & $684(8.6) b$ & $111(5.2) \mathrm{c}$ & $165(5.5) \mathrm{c}$ & \multirow{2}{*}{235.15} & \multirow{2}{*}{3} & \multirow{2}{*}{$<0.001$} & \multirow{2}{*}{0.108} \\
\hline & No depression & $18,334(90.5)$ & $6205(86.6)$ a & $7266(91.4) \mathrm{b}$ & $2020(94.8) \mathrm{c}$ & $2843(94.5) \mathrm{c}$ & & & & \\
\hline Sex & Depression last 12 months & Total & Never & Occasional & Several/month & Several/week & $x^{2}$ & $d f$ & $p^{*}$ & $V$ \\
\hline \multirow{2}{*}{ Men $(n=9716)$} & Depression & $429(4.4)$ & $221(7.1) \mathrm{a}$ & $150(4.0) \mathrm{b}$ & $22(1.9) \mathrm{c}$ & $36(2.2) c$ & \multirow{2}{*}{91.00} & \multirow{2}{*}{3} & \multirow{2}{*}{$<0.001$} & \multirow{2}{*}{0.097} \\
\hline & No depression & $9287(95.6)$ & $2901(92.9) b$ & $3642(96.0) b$ & $1127(98.1) \mathrm{c}$ & $1617(97.8) \mathrm{c}$ & & & & \\
\hline \multirow{2}{*}{ Women $(n=10,533)$} & Depression & $978(9.3)$ & $523(12.9) \mathrm{a}$ & $344(8.3) b$ & $42(4.3) \mathrm{c}$ & $69(5.1) c$ & \multirow{2}{*}{126.80} & \multirow{2}{*}{3} & \multirow{2}{*}{$<0.001$} & \multirow{2}{*}{0.110} \\
\hline & No depression & $9555(90.7)$ & $3517(87.1)$ a & $3812(91.7) \mathrm{b}$ & $940(95.7) \mathrm{c}$ & $1286(94.9) \mathrm{c}$ & & & & \\
\hline \multirow{2}{*}{ Total $(n=20,249)$} & Depression & $1407(6.9)$ & 744 (10.4) a & $494(6.2) \mathrm{b}$ & $64(3.0) \mathrm{c}$ & $105(3.5) \mathrm{c}$ & \multirow{2}{*}{244.58} & \multirow{2}{*}{3} & 50001 & 0110 \\
\hline & No depression & $18,842(93.1)$ & $6418(89.6)$ a & $7454(93.8) \mathrm{b}$ & $2067(97.0) \mathrm{c}$ & $2903(96.5) \mathrm{c}$ & & & $<0.001$ & 0.110 \\
\hline Sex & Diagnosed depression & Total & Never & Occasional & Several/month & Several/week & $x^{2}$ & $d f$ & $p^{*}$ & V \\
\hline $\operatorname{Men}(n-9716)$ & Depression & $534(5.5)$ & $254(8.1) \mathrm{a}$ & $187(4.9) \mathrm{b}$ & $35(3.0) \mathrm{c}$ & $58(3.5) \mathrm{c}$ & 7014 & 3 & $<0001$ & 0085 \\
\hline Women $(n=10,534)$ & Depression & $1213(11.5)$ & $631(15.6)$ a & $424(10.2) b$ & $65(6.6) c$ & $93(6.9) \mathrm{c}$ & 125.71 & 3 & $<0.001$ & 0.109 \\
\hline & No depression & 9321 (88.5) & $3409(84.4)$ a & $3733(89.8) \mathrm{b}$ & $917(93.4) \mathrm{c}$ & $1262(93.1) \mathrm{c}$ & & & & \\
\hline Total $(n=20,250)$ & Depression & $1747(8.6)$ & $885(12.4) \mathrm{a}$ & $611(7.7) \mathrm{b}$ & $100(4.7) \mathrm{c}$ & $151(5.0) \mathrm{c}$ & 226.93 & 3 & $<0.001$ & 0.106 \\
\hline & No depression & $18,503(91.4)$ & $6276(87.6)$ a & 7339 (92.3) b & $2031(95.3) \mathrm{c}$ & $2857(95.0) \mathrm{c}$ & & & & 0.100 \\
\hline Sex & Antidepressants & Total & Never & Occasional & Several/month & Several/week & $x^{2}$ & $d f$ & $p^{*}$ & V \\
\hline Men $(n-9718)$ & Antidepressants & $302(3.1)$ & $160(5.1) \mathrm{a}$ & $104(2.7) \mathrm{b}$ & $17(1.5) \mathrm{c}$ & $21(1.3) c$ & 7252 & 3 & $<0 \cap 001$ & 0086 \\
\hline 1Vien $(n-9) 10)$ & No antidepressants & $9416(96.9)$ & $2963(94.9)$ a & $3686(97.3) b$ & $1134(98.5) \mathrm{c}$ & $1633(98.7) \mathrm{c}$ & 12.02 & 0 & $<0.001$ & 0.000 \\
\hline Women $(n=10.545)$ & Antidepressants & $813(7.7)$ & $431(10.7) \mathrm{a}$ & $293(7.0) \mathrm{b}$ & $37(3.8) c$ & $52(3.8) c$ & 10233 & 3 & $<0001$ & 0099 \\
\hline & No antidepressants & $9732(92.3)$ & 3612 (89.3) a & 3868 (93.0) b & $946(96.2) \mathrm{c}$ & $1306(96.2) \mathrm{c}$ & 102.33 & 3 & $<0.001$ & 0.099 \\
\hline Totol $(n-20262)$ & Antidepressants & 1115 (5.5) & $591(8.2) \mathrm{a}$ & $397(5.0) \mathrm{b}$ & $54(2.5) \mathrm{c}$ & $73(2.4) \mathrm{c}$ & 1000 & 2 & 50001 & 0000 \\
\hline & No antidepressants & 19,148 (94.5) & 6575 (91.8) a & 7554 (95.0) b & $2080(97.5) \mathrm{c}$ & $2939(97.6) \mathrm{c}$ & 190.90 & 0 & $<0.001$ & 0.099 \\
\hline
\end{tabular}

The data presented by absolute and relative frequencies; Depression (Depression diagnosed by a physician); Non-depression (Depression no diagnosed); Antidepressants (have taken antidepressants in the last two weeks); No antidepressants (have not taken antidepressants in the last two weeks); Frequency of PA ("Which of these possibilities best describes the antidepressants in the last two weeks); No antidepressants (have not taken antidepressants in the last two weeks); Frequency of PA ("Which of these possibilities best describes the
frequency with which you do some physical activity in your free time?"); $p^{*}(p$-value. Chi-square statistic); $d f$ (degree freedom); (Cramer's V); abc (Each subscript corresponds to significant differences between column proportions at 95\%); $n$ (participants). 
Table 4. Relationship between the prevalence of depression (lifetime, in the last 12 years and diagnosed) and the number of days of physical activity per week in the general Spanish population of the EESE 2020 between 18 and 84 years of age, and by sex.

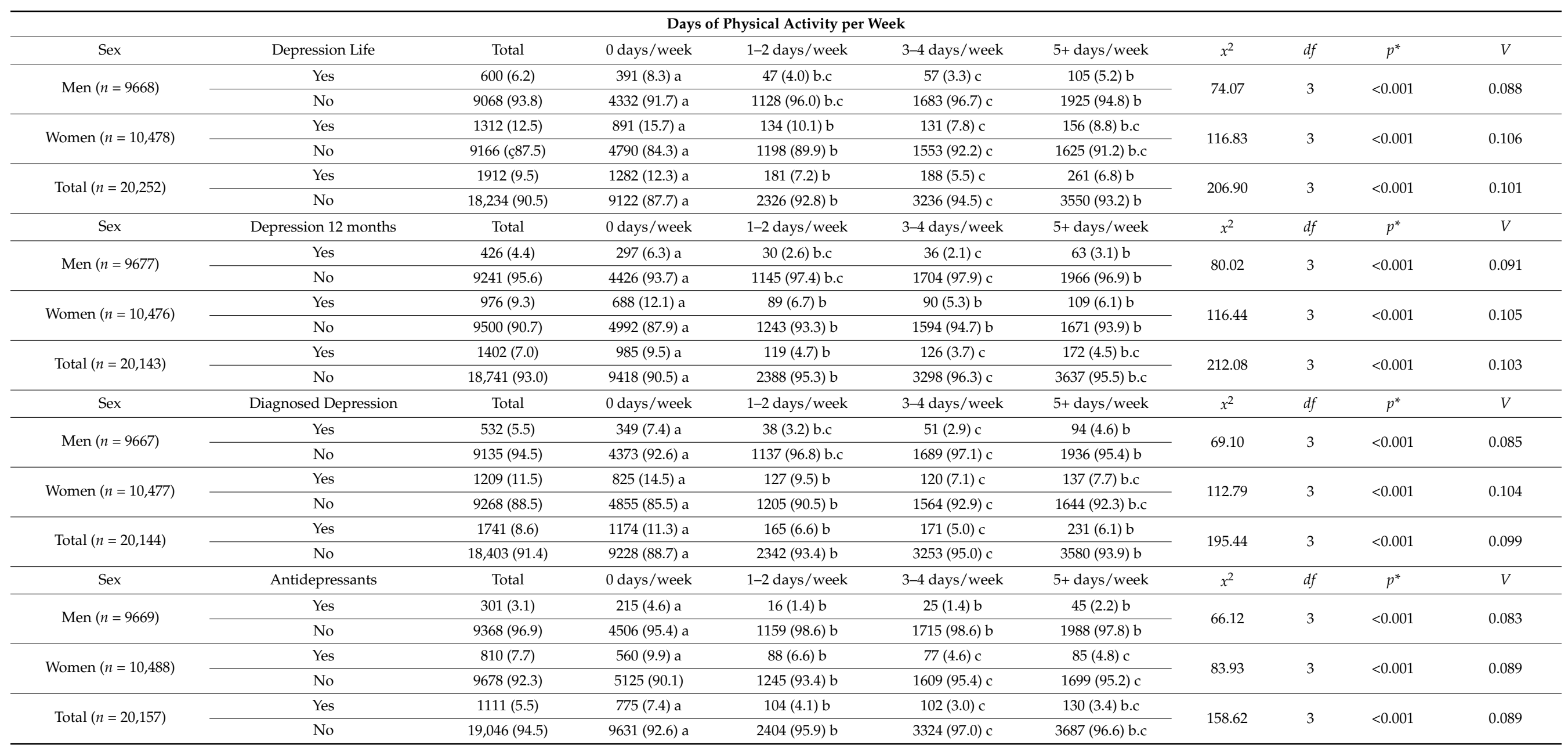

The data are presented by absolute and relative frequencies; Depression (Depression diagnosed by a physician); Non-depression (Depression no diagnosed); Antidepressants (have taken antidepressants in the last 2 weeks); No antidepressants (have not taken antidepressants in the last two weeks); Days PA (how many days do you practice sport, gymnastics, cycling, brisk walking, etc., at least $10 \mathrm{~min}$ at a time); $p^{*}(p$-value. Chi-square statistic); $d f$ (degree freedom); $V$ (Cramer's V); abc (Each subscript corresponds to significant differences between column proportions at $95 \%) ; n$ (participants). 
In each age group, the prevalence of depression that was suffered at any time in life was found to be related to the frequency of PA. In the young general population, the prevalence of depression reached $3.2 \%$. In inactive young people, the prevalence was found to be 2.1 percentage points higher than the average $(5.3 \%)$, while the prevalence decreased to $1.3 \%$ in those who performed PA several times a month. In the elderly, the prevalence in inactive persons was $19.8 \%, 10.6$ percentage points higher than in the elderly with PA several times a month (9.2\%). In any age group, significant differences were found in the prevalence of depression at any time of life between inactive persons and the rest of the PA groups, although not between them $(p<0.05)$. The same relationships and differences were found in the prevalence of diagnosed depression. On the other hand, although the previous dependency relationships were again found in the prevalence of depression in the last 12 months in all age groups, in adults and the elderly, differences were found between performing PA occasionally and performing PA several times a month, or more, with lower prevalence in the latter $(p<0.05)$. In the elderly, the prevalence of depression in the last 12 months was tripled in inactive persons (15.7\%) compared to those who performed PA several times a month (4.7\%), with $p<0.05$. Regarding the prevalence of taking antidepressants, dependence relationships were found with the frequency of PA in all age groups. In adults and the elderly, significant differences were found between the prevalence of inactive people and the rest of the groups $(p<0.05)$ (Table 6).

The results were not very different when analyzing the relationships between the prevalence of depression in each of the conditions and the PA groups, according to the days per week. Dependency relationships were found in all of them and in all age groups. A lower prevalence was found in all groups with one PA day per week, or more, compared to the inactive group, with $p<0.05$. In young people, between the inactive $(5.3 \%)$ and the groups with the highest number of PA days per week reached 3.6 percentage points, these differences reached 8 percentage points in the elderly ( 0 days/week: $17.2 \%$ vs. 5+days/week: $9.2 \%$ ) in the prevalence of depression that was suffered throughout life, with similar differences in the prevalence of depression in the last 12 months and in diagnosed depression. The prevalence of taking antidepressants was also related to the days of PA per week in all age groups. Although significant differences were found between then inactive and the rest of the groups, no differences were found in the latter among themselves $(p<0.05)$. However, in young people and the elderly, no differences were found between the inactive people and those who performed PA 1-2 days a week, or between these and the rest of the groups $(p<0.05)$ (Table 7$)$.

Finally, dependency relationships were found between the prevalence of depression in the three conditions that were analyzed and the days per week of muscle strengthening activities in all the age groups. In all the age groups, significant differences were found between the prevalence of the inactive groups and those who performed strengthening activities one to two times per week $(p<0.05)$, being lower in the latter. However, the same did not occur with the prevalence of all the groups with a greater number of days per week, finding increased prevalence with respect to those of the one to two days per week group. Similarly, dependence relationships were found between the prevalence of taking antidepressants and the number of days of strengthening activities in all the age groups, although significant differences were only found between some groups, with the highest prevalence in the group of young people in the group of five days or more per week, although without significant differences with the inactive group. In the rest of the age groups, although with lower prevalence, the differences between the two groups were not significant either, although they were significant with other groups (Table 8). 
Table 5. Relationship between the prevalence of depression (lifetime, in the last 12 years and diagnosed) and days of muscle-strengthening training per week in the general Spanish population of EESE 2020 between 18 and 84 years of age, and by sex.

\begin{tabular}{|c|c|c|c|c|c|c|c|c|c|c|}
\hline \multicolumn{11}{|c|}{ Muscle Strengthening Days per Week } \\
\hline Sex & Depression Life & Total & 0 days/week & 1-2 days/week & 3-4 days/week & 5+ days/week & $x^{2}$ & $d f$ & $p^{*}$ & V \\
\hline \multirow{2}{*}{ Men $(n=9637)$} & Yes & $600(6.2)$ & $527(6.9)$ a & $22(3.2) b$ & $31(3.8) b$ & $20(4.2) \mathrm{b}$ & \multirow{2}{*}{27.27} & \multirow{2}{*}{3} & \multirow{2}{*}{$<0.001$} & \multirow{2}{*}{0.053} \\
\hline & No & $9037(93.8)$ & $7143(93.1)$ a & $659(96.8) b$ & $781(96.2) \mathrm{b}$ & 454 (95.8) b & & & & \\
\hline Women $(n=10,450)$ & No & $9139(87.5)$ & $7559(86.2)$ a & $746(95.0) \mathrm{b}$ & $536(92.9) \mathrm{b}$ & $298(93.4) b$ & 79.53 & 3 & $<0.001$ & 0.087 \\
\hline \multirow{2}{*}{ Total $(n=20,087)$} & Yes & $1911(9.5)$ & $1737(10.6) \mathrm{a}$ & $61(4.2) \mathrm{b}$ & $72(5.2) b$ & $41(5.2) b$ & \multirow{2}{*}{117.58} & \multirow{2}{*}{3} & \multirow{2}{*}{$<0.001$} & \multirow{2}{*}{0.077} \\
\hline & No & $18,176(90.5)$ & $14,702(89.4)$ a & $1405(7.7) \mathrm{b}$ & $1317(94.8) \mathrm{b}$ & $752(94.8) \mathrm{b}$ & & & & \\
\hline Sex & Depression 12 months & Total & 0 days/week & 1-2 days/week & 3-4 days/week & $5+$ days/week & $x^{2}$ & $d f$ & $p^{*}$ & $V$ \\
\hline \multirow{2}{*}{$\operatorname{Men}(n=9636)$} & Yes & $426(4.4)$ & $383(5.0) \mathrm{a}$ & $14(2.1) b$ & $18(2.2) b$ & $11(2.3) b$ & \multirow{2}{*}{29.22} & \multirow{2}{*}{3} & \multirow{2}{*}{$<0.001$} & \multirow{2}{*}{0.055} \\
\hline & No & $9210(95.6)$ & $7287(95.0)$ a & $667(97.9) \mathrm{b}$ & $794(97.8) b$ & $462(97.7) \mathrm{b}$ & & & & \\
\hline \multirow{2}{*}{ Women $(n=10,448)$} & Yes & $976(9.3)$ & $906(10.3) \mathrm{a}$ & $21(2.7) \mathrm{b}$ & $34(5.9) \mathrm{c}$ & $15(4.7)$ b.c & \multirow{2}{*}{67.51} & \multirow{2}{*}{3} & \multirow{2}{*}{$<0.001$} & \multirow{2}{*}{0.080} \\
\hline & No & $9472(90.7)$ & $7862(89.7)$ a & $764(97.3) b$ & $543(94.1) c$ & $303(95.3)$ b.c & & & & \\
\hline \multirow{2}{*}{ Total $(n=20,084)$} & Yes & $1402(7.0)$ & $1289(7.8) \mathrm{a}$ & $35(2.4) b$ & $52(3.7) \mathrm{c}$ & $26(3.3)$ b.c & \multirow{2}{*}{105.43} & \multirow{2}{*}{3} & 10001 & (2007 \\
\hline & No & $18,682(93.0)$ & $15,149(92.2) \mathrm{a}$ & $1431(97.6) \mathrm{b}$ & $1337(96.3) \mathrm{c}$ & 765 (96.7) b.c & & & $<0.001$ & 0.072 \\
\hline Sex & Diagnosed Depression & Total & 0 days/week & 1-2 days/week & 3-4 days/week & 5+ days/week & $x^{2}$ & $d f$ & $p^{*}$ & V \\
\hline $\operatorname{Men}(n=9636)$ & Yes & $532(5.5)$ & $463(6.0)$ a & $18(2.6) \mathrm{b}$ & $31(3.8) \mathrm{b}$ & $20(4.2)$ a.b & 20.79 & 3 & $<0.001$ & 0.046 \\
\hline Women $(n=10,449)$ & Yes & $1208(11.6)$ & $1121(12.8) \mathrm{a}$ & $33(4.2) \mathrm{b}$ & $39(6.8) c$ & $15(4.7)$ b.c & 82.10 & 3 & $<0.001$ & 0.089 \\
\hline vormen $(n=10,449)$ & No & $9241(88.4)$ & $7647(87.2) \mathrm{a}$ & $752(95.8) b$ & $538(93.2) \mathrm{c}$ & $304(95.3)$ b.c & 82.10 & 3 & $<0.001$ & 0.089 \\
\hline Total $(n=20,085)$ & Yes & $1740(8.7)$ & $1584(9.6)$ a & $51(3.5) \mathrm{b}$ & $70(5.0) \mathrm{c}$ & $35(4.4)$ b.c & 110.62 & 3 & $<0.001$ & 0.074 \\
\hline & No & $18,345(91.3)$ & $14,853(90.4)$ a & $1415(96.5) \mathrm{b}$ & $1319(95.0) \mathrm{c}$ & 758 (95.6) b.c & & & & \\
\hline Sex & Antidepressants & Total & 0 days/week & 1-2 days/week & 3-4 days/week & 5+ days/week & $x^{2}$ & $d f$ & $p^{*}$ & $V$ \\
\hline $\operatorname{Men}(n-9638)$ & Yes & $301(3.1)$ & $268(3.5) \mathrm{a}$ & $13(1.9) \mathrm{b}$ & $11(1.4) b$ & $9(1.9)$ a.b & 1760 & 3 & $<0001$ & 0043 \\
\hline IVIEn $(n-3000)$ & No & $9368(96.9)$ & 7401 (96.5) a & $668(98.1) b$ & $802(98.6) b$ & 466 (98.1) a.b & 17.00 & 0 & $<0.001$ & 0.045 \\
\hline Women $(n=10460)$ & Yes & 809 (7.7) & $743(8.5) \mathrm{a}$ & $25(3.2) b$ & $23(4.0) \mathrm{b}$ & 18 (5.6) a.b & 4279 & 3 & $<0001$ & 0064 \\
\hline & No & 9651 (92.3) & $8034(91.5)$ a & $761(96.8) b$ & $555(96.0) b$ & 301 (94.4) a.b & 42.79 & 3 & $<0.001$ & 0.064 \\
\hline Total $(n=20098)$ & Yes & $1111(5.5)$ & $1011(6.1) \mathrm{a}$ & $38(2.6) b$ & $34(2.4) b$ & $27(3.4) b$ & 6859 & 3 & $\leq 0001$ & 0058 \\
\hline 10 tar $(n-20,070)$ & No & 19,046 (94.5) & 15,435 (93.8) a & $1429(97.4) b$ & $1357(97.6) b$ & $767(96.6) b$ & 68.59 & 3 & $<0.001$ & 0.038 \\
\hline
\end{tabular}

The data are presented by absolute and relative frequencies; Depression (Depression diagnosed by a physician); Non-depression (Depression no diagnosed); Antidepressants (have taken antidepressants in the last two weeks); No antidepressants (have not taken antidepressants in the last two weeks); Strengthening days (how many days do you do activities specifically aimed at strengthening your muscles); $p^{*}(p$-value. Chi-square statistic); $d f$ (degree freedom); $V$ (Cramer's V); abc (Each subscript corresponds to significant differences between column proportions at $95 \%) ; n$ (participants). 
Table 6. Relationship between the prevalence of depression (lifetime, past 12 years and diagnosed) and the frequency of physical activity in the general Spanish population of EESE 2020 between 18 and 84 years, by age group.

\begin{tabular}{|c|c|c|c|c|c|c|c|c|c|c|}
\hline \multicolumn{11}{|c|}{ Frequency of Physical Activity } \\
\hline Age & Depression Life & Total & Never & Occasional & Several/month & Several/week & $x^{2}$ & $d f$ & $p^{*}$ & $V$ \\
\hline Young people & Yes & $93(3.2)$ & $46(5.3) \mathrm{a}$ & $27(3.0) b$ & $6(1.3) b$ & $14(2.0) \mathrm{b}$ & 20.81 & 3 & $<0.001$ & 0.085 \\
\hline Young adults & Yes & $334(5.9)$ & $159(8.5) \mathrm{a}$ & $104(5.3) b$ & $31(4.1) b$ & $40(3.9) b$ & 35.77 & 3 & $<0.001$ & 0.080 \\
\hline Older Adults & Yes & $622(10.7)$ & $281(13.8) \mathrm{a}$ & $241(9.6) b$ & $39(7.3) b$ & $61(8.1) b$ & 36.30 & 3 & $<0.001$ & 0.079 \\
\hline Older & Yes & $869(14.8)$ & $472(19.8) \mathrm{a}$ & $312(12.1) b$ & $35(9.2) \mathrm{b}$ & $50(9.5) b$ & 82.69 & 3 & $<0.001$ & 0.119 \\
\hline Total & Yes & $1918(9.5)$ & $958(13.4) \mathrm{a}$ & $684(8.6) b$ & $111(5.2) \mathrm{c}$ & $165(5.5) c$ & 235.2 & 3 & $<0.001$ & 0.108 \\
\hline Age & Depression 12 months & Total & Never & Occasional & Several/month & Several/week & $x^{2}$ & $d f$ & $p^{*}$ & $V$ \\
\hline Young people & Yes & $65(2.2)$ & $30(3.4) a$ & $20(2.2) \mathrm{ab}$ & $4(0.9) \mathrm{b}$ & $11(1.6) b$ & 11.14 & 3 & 0.011 & 0.062 \\
\hline Young adults & Yes & $237(4.2)$ & $118(6.3) \mathrm{a}$ & $79(4.0) \mathrm{b}$ & $17(2.3) \mathrm{c}$ & $23(2.2) c$ & 37.69 & 3 & $<0.001$ & 0.082 \\
\hline Older Adults & Yes & $464(8.0)$ & $221(10.9)$ a & $180(7.2) b$ & $25(4.7) \mathrm{c}$ & $38(5.0) c$ & 42.68 & 3 & $<0.001$ & 0.086 \\
\hline Older & Yes & $641(10.9)$ & $375(15.7)$ a & $215(8.3) b$ & $18(4.7) \mathrm{c}$ & $33(6.3)$ b.c & 100.5 & 3 & $<0.001$ & 0.131 \\
\hline Total & Yes & $1407(6.9)$ & $744(10.4) \mathrm{a}$ & $494(6.2) b$ & $64(3.0) c$ & $105(3.5) \mathrm{c}$ & 244.6 & 3 & $<0.001$ & 0.110 \\
\hline Age & Diagnosed Depression & Total & Never & Occasional & Several/month & Several/week & $x^{2}$ & $d f$ & $p^{*}$ & $V$ \\
\hline Young people & Yes & $81(2.8)$ & $40(4.6) \mathrm{a}$ & $22(2.5) b$ & $5(1.1) b$ & $14(2.0) b$ & 17.30 & 3 & 0.001 & 0.077 \\
\hline Older Adults & Yes & $573(9.8)$ & $263(13.0) \mathrm{a}$ & $221(8.8) b$ & $36(6.7) b$ & $53(7.0) b$ & 38.00 & 3 & $<0.001$ & 0.081 \\
\hline Older & Yes & $788(13.4)$ & $432(18.1) \mathrm{a}$ & $278(10.8) b$ & $32(8.4) b$ & $46(8.8) b$ & 78.56 & 3 & $<0.001$ & 0.116 \\
\hline Total & Yes & $1747(8.6)$ & 885 (12.4) a & $611(7.7) \mathrm{b}$ & $100(4.7) \mathrm{c}$ & $151(5.0) \mathrm{c}$ & 226.93 & 3 & $<0.001$ & 0.106 \\
\hline Age & Antidepressants & Total & Never & Occasional & Several/month & Several/week & $x^{2}$ & $d f$ & $p^{*}$ & $V$ \\
\hline Young people & Yes & $47(1.6)$ & $23(2.6) \mathrm{a}$ & $11(1.2) b$ & $5(1.1) a b$ & $8(1.2) b$ & 8.31 & 3 & 0.040 & 0.053 \\
\hline Young adults & Yes & 197 (3.5) & $100(5.3) \mathrm{a}$ & $63(3.2) b$ & $15(2.0)$ b.c & $19(1.8) \mathrm{c}$ & 32.79 & 3 & $<0.001$ & 0.076 \\
\hline Older Adults & Yes & $386(6.6)$ & $192(9.5) \mathrm{a}$ & $151(6.0) b$ & $19(3.5) \mathrm{c}$ & $24(3.2) c$ & 51.01 & 3 & $<0.001$ & 0.094 \\
\hline Older & Yes & 485 (8.2) & 276 (11.5) a & $172(6.7) b$ & $15(3.9) \mathrm{c}$ & $22(4.2) c$ & 63.73 & 3 & $<0.001$ & 0.104 \\
\hline Total & Yes & $1115(5.5)$ & $591(8.2) \mathrm{a}$ & $397(5.0) b$ & $54(2.5) c$ & $73(2.4) \mathrm{c}$ & 199 & 3 & $<0.001$ & 0.099 \\
\hline
\end{tabular}


Table 7. Relationship between the prevalence of depression (lifetime, past 12 years and diagnosed) and days of physical activity in the general Spanish population of the EESE 2020 between 18 and 84 years, by age group.

\begin{tabular}{|c|c|c|c|c|c|c|c|c|c|c|}
\hline \multicolumn{11}{|c|}{ Days of Physical Activity per Week } \\
\hline Age & Depression Life & Total & 0 days/week & 1-2 days/week & 3-4 days/week & $5+$ days/week & $x^{2}$ & $d f$ & $p^{*}$ & $V$ \\
\hline Young people & Yes & $93(3.2)$ & $60(5.3) \mathrm{a}$ & $11(2.4) \mathrm{b}$ & $13(1.7) \mathrm{b}$ & $9(1.7) \mathrm{b}$ & 20.81 & 3 & $<0.001$ & 0.085 \\
\hline Young adults & Yes & $334(6.0)$ & $205(8.0) \mathrm{a}$ & $50(5.4) b$ & $40(3.3) \mathrm{c}$ & $39(4.2)$ b.c & 35.77 & 3 & $<0.001$ & 0.080 \\
\hline Older Adults & Yes & $618(10.7)$ & $384(12.7)$ a & $60(7.8) b$ & $75(8.3) b$ & $99(9.0) \mathrm{b}$ & 36.30 & 3 & $<0.001$ & 0.079 \\
\hline Older & Yes & $867(14.8)$ & $633(17.2) \mathrm{a}$ & $60(16.5)$ a & $60(10.9) \mathrm{b}$ & $114(9.2) \mathrm{b}$ & 82.69 & 3 & $<0.001$ & 0.119 \\
\hline Total & Yes & $1912(9.5)$ & $1282(12.3) \mathrm{a}$ & $181(7.2) b$ & $188(5.5) \mathrm{c}$ & $261(6.8) b$ & 235.2 & 3 & $<0.001$ & 0.108 \\
\hline Age & Depression 12 months & Total & 0 days/week & 1-2 days/week & 3-4 days/week & 5+ days/week & $x^{2}$ & $d f$ & $p^{*}$ & $V$ \\
\hline Young people & Yes & $65(2.2)$ & $40(3.5) \mathrm{a}$ & $9(2.0)$ a.b & $7(0.9) \mathrm{b}$ & $9(1.7) \mathrm{b}$ & 26.01 & 3 & $<0.001$ & 0.095 \\
\hline Young adults & Yes & $237(4.2)$ & $156(6.1) \mathrm{a}$ & $30(3.2) b$ & $27(2.3) b$ & $24(2.6) b$ & 39.70 & 3 & $<0.001$ & 0.084 \\
\hline Older Adults & Yes & $461(7.9)$ & $295(9.8)$ a & $37(4.8) b$ & $52(5.7) b$ & $77(7.0) b$ & 29.13 & 3 & $<0.001$ & 0.071 \\
\hline Older & Yes & $639(10.9)$ & $494(13.4) \mathrm{a}$ & $43(11.8)$ & $40(7.3) \mathrm{b}$ & $62(5.0) b$ & 54.18 & 3 & $<0.001$ & 0.096 \\
\hline Total & Yes & $1402(7.0)$ & $985(9.5)$ a & $119(4.7) \mathrm{b}$ & $126(3.7) \mathrm{c}$ & $172(4.5)$ b.c & 206.90 & 3 & $<0.001$ & 0.101 \\
\hline Age & Diagnosed Depression & Total & 0 days/week & 1-2 days/week & 3-4 days/week & $5+$ days/week & $x^{2}$ & $d f$ & $p^{*}$ & $V$ \\
\hline Young people & Yes & $81(2.8)$ & $51(4.5)$ a & $11(2.4)$ a.b & $10(1.3) b$ & $9(1.7) \mathrm{b}$ & 22.73 & 3 & 0.001 & 0.085 \\
\hline Older Adults & Yes & $569(9.8)$ & 359 (11.9) a & $53(6.9) b$ & $70(7.7) b$ & $87(7.9) b$ & 31.63 & 3 & $<0.001$ & 0.074 \\
\hline Older & Yes & 786 (13.5) & $577(15.6) \mathrm{a}$ & 57 (15.7) a & $54(9.8) b$ & $98(7.9) \mathrm{b}$ & 55.55 & 3 & $<0.001$ & 0.098 \\
\hline Total & Yes & $1741(8.6)$ & $1174(11.3) \mathrm{a}$ & $165(6.6) b$ & $171(5.0) \mathrm{c}$ & $231(6.1) b$ & 195.44 & 3 & $<0.001$ & 0.099 \\
\hline Age & Antidepressants & Total & 0 days/week & 1-2 days/week & 3-4 days/week & $5+$ days/week & $x^{2}$ & $d f$ & $p^{*}$ & $V$ \\
\hline Young people & Yes & $47(1.6)$ & $28(2.5) \mathrm{a}$ & $11(2.4) \mathrm{a}$ & $4(0.5) b$ & $4(0.7) \mathrm{b}$ & 15.25 & 3 & 0.002 & 0.073 \\
\hline Young adults & Yes & $197(3.5)$ & $126(4.9) \mathrm{a}$ & $25(2.7) \mathrm{b}$ & $23(1.9) \mathrm{b}$ & $23(2.5) b$ & 28.84 & 3 & $<0.001$ & 0.072 \\
\hline Older Adults & Yes & 384 (6.6) & $254(8.4) \mathrm{a}$ & $31(4.0) \mathrm{b}$ & $44(4.8) \mathrm{b}$ & $55(5.0) \mathrm{b}$ & 33.91 & 3 & $<0.001$ & 0.076 \\
\hline Older & Yes & $483(8.3)$ & 367 (9.9) a & $37(10.2) \mathrm{a}$ & $31(5.6) b$ & $48(3.9) \mathrm{b}$ & 51.99 & 3 & $<0.001$ & 0.094 \\
\hline Total & Yes & $1115(5.5)$ & $775(7.4) \mathrm{a}$ & $104(4.1) b$ & $102(3.0) \mathrm{c}$ & $130(3.4)$ b.c & 158.6 & 3 & $<0.001$ & 0.089 \\
\hline
\end{tabular}


Table 8. Relationship between the prevalence of depression (lifetime, past 12 years and diagnosed) and days of muscle-strengthening training per week in the general Spanish population of EESE 2020 between 18 and 84 years, by age group.

\begin{tabular}{|c|c|c|c|c|c|c|c|c|c|c|}
\hline \multicolumn{11}{|c|}{ Muscle Strengthening Days per Week } \\
\hline Age & Depression Life & Total & 0 days/week & 1-2 days/week & 3-4 days/week & $5+$ days/week & $x^{2}$ & $d f$ & $p^{*}$ & $V$ \\
\hline Young people & Yes & $93(3.2)$ & $79(4.2) \mathrm{a}$ & $3(0.9) b$ & $6(1.4) b$ & $5(2.4) a . b$ & 16.73 & 3 & 0.001 & 0.076 \\
\hline Young adults & Yes & $333(6.0)$ & $283(6.7) \mathrm{a}$ & $21(3.6) b$ & $23(4.4)$ a.b & $6(2.5) b$ & 16.83 & 3 & 0.001 & 0.055 \\
\hline Older Adults & Yes & $618(10.7)$ & $558(11.3)$ a & $23(6.5) b$ & $26(9.1)$ a.b & $11(6.0) b$ & 13.25 & 3 & 0.004 & 0.048 \\
\hline Older & Yes & $867(14.9)$ & $817(15.3) \mathrm{a}$ & $14(8.0) \mathrm{b}$ & 17 (10.6) a.b & 19 (12.2) a.b & 10.67 & 3 & 0.014 & 0.043 \\
\hline Total & Yes & $1911(9.5)$ & 1737 (10.6) a & $61(4.2) b$ & $72(5.2) b$ & $41(5.2) b$ & 117.6 & 3 & $<0.001$ & 0.077 \\
\hline Age & Depression 12 months & Total & 0 days/week & 1-2 days/week & 3-4 days/week & 5+ days/week & $x^{2}$ & $d f$ & $p^{*}$ & $V$ \\
\hline Young people & Yes & $65(2.3)$ & $54(2.8) \mathrm{a}$ & $1(0.3) b$ & $5(1.2)$ b.c & $5(2.5)$ a. c & 11.49 & 3 & 0.009 & 0.063 \\
\hline Young adults & Yes & $237(4.2)$ & $204(4.8) \mathrm{a}$ & $11(1.9) \mathrm{b}$ & 17 (3.3) a.b & $5(2.1) b$ & 15.19 & 3 & 0.002 & 0.052 \\
\hline Older Adults & Yes & $461(8.0)$ & $419(8.4) \mathrm{a}$ & $14(3.9) b$ & $20(7.0)$ a.b & $8(4.4) a . b$ & 12.98 & 3 & 0.005 & 0.047 \\
\hline Older & Yes & $639(11.0)$ & $612(11.5) \mathrm{a}$ & $9(5.1) b$ & $10(6.3) b$ & $8(5.2) b$ & 16.60 & 3 & 0.001 & 0.053 \\
\hline Total & Yes & $1402(7.0)$ & $1289(7.8) \mathrm{a}$ & $35(2.4) b$ & $52(3.7) c$ & $26(3.3)$ b.c & 105.4 & 3 & $<0.001$ & 0.072 \\
\hline Age & Diagnosed Depression & Total & 0 days/week & 1-2 days/week & 3-4 days/week & 5+ days/week & $x^{2}$ & $d f$ & $p^{*}$ & V \\
\hline Young people & Yes & $81(2.8)$ & $69(3.6) \mathrm{a}$ & $1(0.3) b$ & $6(1.4) b$ & $5(2.4)$ a.b & 16.21 & 3 & 0.001 & 0.075 \\
\hline Older Adults & Yes & $569(9.8)$ & $514(10.4) \mathrm{a}$ & $20(5.6) b$ & $26(9.1)$ a.b & $9(4.9) \mathrm{b}$ & 13.86 & 3 & 0.003 & 0.049 \\
\hline Older & Yes & $786(13.5)$ & $742(13.9) \mathrm{a}$ & $13(7.4) b$ & 16 (10.0) a.b & 15 (9.6) a.b & 10.14 & 3 & 0.017 & 0.042 \\
\hline Total & Yes & $1740(8.7)$ & $1584(9.6) \mathrm{a}$ & $51(3.5) b$ & $70(5.0) \mathrm{c}$ & $35(4.4)$ b.c & 110.64 & 3 & $<0.001$ & 0.074 \\
\hline Age & Antidepressants & Total & 0 days/week & 1-2 days/week & 3-4 days/week & 5+ days/week & $x^{2}$ & $d f$ & $p^{*}$ & V \\
\hline Young people & Yes & $47(1.6)$ & $36(1.9) \mathrm{a}$ & $2(0.6) \mathrm{a}$ & $4(0.9) \mathrm{a}$ & $5(2.4) \mathrm{a}$ & 5.29 & 3 & 0.152 & 0.043 \\
\hline Young adults & Yes & $196(3.5)$ & $167(3.9) \mathrm{a}$ & $13(2.2) b$ & $10(1.9) \mathrm{b}$ & $6(2.5)$ a.b & 9.61 & 3 & 0.022 & 0.041 \\
\hline Older Adults & Yes & $384(6.6)$ & $350(7.1) \mathrm{a}$ & $12(3.4) b$ & 14 (4.9) a.b & $8(4.4)$ a.b & 10.45 & 3 & 0.015 & 0.043 \\
\hline Older & Yes & $483(8.3)$ & $458(8.6) \mathrm{a}$ & $11(6.2) a . b$ & $6(3.7) b$ & 8 (5.1) a.b & 8.07 & 3 & 0.045 & 0.037 \\
\hline Total & Yes & $1110(5.5)$ & 1011 (6.1) a & $38(2.6) b$ & $34(2.4) \mathrm{b}$ & $27(3.4) b$ & 68.59 & 3 & $<0.001$ & 0.058 \\
\hline
\end{tabular}




\section{Discussion}

The first finding of our study was in relation to sex. Significant differences were found $(p<0.05)$, as noted in most studies, where being female is a risk factor that is associated with depression [31,32]. Likewise, dependency relationships were found between age group and sex, with women presenting a higher proportion of the population with depression than men in the elderly group; this is consistent with the majority of studies indicating that depression is higher in older women [33-35].

Regarding age, the median age of the population that was studied was 54 years, being lower in men (53) than in women (55), with significant differences between the two $(p<0.001)$. It may be related to the onset of menopause in women, as indicated by other studies [36,37].

The prevalence of depression that was suffered at some point in life was $9.5 \%$ in the general population, the same as the ENSE 2017 survey, whose figure stands at $9.2 \%$. Dependent relationships were found between the prevalence of depression and sex, with women $(12.5 \%)$ presenting a prevalence twice that of men $(6.2 \%)$, with significant differences between the two $(p<0.05)$. Similar results were found in the prevalence of depression in the last 12 months and diagnosed by a physician (8.6\%) in the general population, as noted in most studies, where being female is a risk factor that is associated with depression $[31,32]$.

Also, dependence relationships were found between the prevalence of taking antidepressants and sex, being more than twice as high in women $(7.7 \%)$ than in men $(3.1 \%)$, with statistically significant differences between both $(p<0.05)$. This is in line with other studies $[38,39]$ where the prevalence of antidepressant use is twice as high in women as in men.

Similarly, dependency relationships were found between PA frequency and sex. The rate of inactive women is higher than that of men, as reported in other studies [40,41]. In terms of strength work, women perform less strengthening exercises with $p<0.05$ [42].

Another important finding is that dependence relationships were found between the prevalence of depression (lifetime, in the last 12 months and diagnosed) and the frequency of PA, both in the general population and in both sexes. The higher the frequency of physical activity, the lower the prevalence of depression. There are several studies and systematic reviews supporting this finding [43-45]. The prevalence of taking antidepressants showed dependence relationships with the frequency of PA; in this line there is another study where the probability of taking antidepressants increases with inactivity [46].

The existence of dependency relationships between the prevalence of the three depression conditions that were analyzed in this research and the number of days per week that muscle strengthening activities were performed were also found, both in the general population and in both sexes; coinciding with the systematic review on physical exercise and depression $[47,48]$. In all the age groups, significant differences were found between the prevalence of the inactive groups and those who performed strengthening activities one to two times per week $(p<0.05)$, being lower in the latter. However, the same did not occur with a higher number of days per week, with increased prevalence.

If we know the recommended frequency of physical activity and the type of exercise to prevent or reduce the prevalence of depression in different age groups, our findings could be a reference for monitoring the prevalence of current depressive disorders, planning health resources and services, and developing screening and preventive strategies in different age groups at the national level.

\subsection{Theoretical and Practical Implications}

Health education and promotion campaigns among the Spanish population could help to reduce the prevalence of depression in all the age groups. Increasing the frequency of PA in inactive people or those with low levels of PA to three to four days/week of moderate physical activity, including one to two days of strength work, could reduce the prevalence of depression and antidepressant use in the Spanish population. 
Possible initiatives that governmental policies could carry out could be: from including active breaks in high schools and universities for the youth group; physical activity programs in companies for adults, to active aging programs for the elderly.

\subsection{Limitations}

This article has some limitations to take into account: it is cross-sectional in nature. The data were obtained through the information that was submitted by the participants. Cause-effect relationships cannot be established due to the methodology that was used. Only male and female sex is considered; non-binary sex is not taken into account. Physical activity measures were not objectively assessed. Only whether or not participants were taking antidepressants was recorded; neither the active ingredient nor the amount taken by each participant who reported taking antidepressants was recorded. Other variables that could affect depression, such as sociodemographic, socioeconomic, and the sociocultural biases of the participants, were also not included, because although there are studies in which these variables seem to affect depression $[49,50]$, this greatly reduced the sample by including new divisions in the groups, losing statistical power.

\section{Conclusions}

There is an inverse relationship between physical activity and the probability of suffering from depression and the intake of antidepressants. The higher the frequency of physical exercise, the lower the prevalence of depression and the lower the intake of antidepressants. Performing PA three to four days/week, including one to two days of strength work, could be the best proposal to reduce the prevalence of depression in the Spanish population.

Author Contributions: Conceptualization, C.G.-A., J.R.-R., Á.D.-Z. and J.C.A.; Formal analysis, C.G.A., D.P.-P., J.R.-R. and Á.D.-Z.; Funding acquisition, E.M.-N.; Methodology, C.G.-A., M.A.H.-M., Á.D.-Z. and J.C.A.; Project administration, C.G.-A.; Supervision, M.A.H.-M., E.M.-N., J.P.-G. and J.C.A.; writing-original draft, C.G.-A., D.P.-P., J.R.-R. and Á.D.-Z.; writing-review \& editing, C.G.A., D.P.-P., J.R.-R., M.A.H.-M., E.M.-N., J.P.-G., Á.D.-Z. and J.C.A. All authors have read and agreed to the published version of the manuscript.

Funding: Proyecto 4IE + (0499_4IE_PLUS_4_E); Programa Interreg VA España-Portugal (POCTEP) 2014-2020: 0499_4IE_PLUS_4_E; Desarrollo del Observatorio El Ejercicio Te Cuida (02/03/202101/03/2023); The author Á.D.-Z. (FPU20/04201) was supported by a grant from the Spanish Ministry of Education, Culture, and Sport. Grants FPU20/04201 funded by MCIN/AEI/ 10.13039/501100011033 and, as appropriate, by "European Social Found Investing in your future" or by "European Union NextGenerationEU/PRTR".

Institutional Review Board Statement: Due to the characteristics of the research, given that the data were obtained from non-confidential, open-access public files published by the MSCBS, the supervision and authorization of any official ethics committee was not necessary.

Informed Consent Statement: Not required, since the data were obtained from anonymous, nonconfidential public files.

Data Availability Statement: The data used were obtained from public use files, which are available on the website of the Spanish Ministry of Health, Consumer Affairs, and Social Welfare: https: / /www. sanidad.gob.es/estadEstudios/estadisticas/EncuestaEuropea/Enc_Eur_Salud_en_Esp_2020.htm (accessed on 5 November 2021).

Acknowledgments: This article has been made possible thanks to the project "Observatorio El Ejercicio Te Cuida" signed between the Fundación Jóvenes y Deporte de la Junta de Extremadura and the University of Extremadura.

Conflicts of Interest: The authors declare no conflict of interest. 


\section{References}

1. Morales Fuhrimann, C. La depresión: Un reto para toda la sociedad del que debemos hablar. Rev. Cuba. Salud Pública 2017, 43, 136-138.

2. Lang, U.E.; Borgwardt, S. Molecular mechanisms of depression: Perspectives on new treatment strategies. Cell. Physiol. Biochem. 2013, 31, 761-777. [CrossRef] [PubMed]

3. Metrics, I.f.H.; Resources, E.J. Global Health Data Exchange; Global Burden of Disease Study 2017 Data Resources. Available online: http:/ / ghdx.healthdata.org/gbd-2017 (accessed on 5 November 2021).

4. Cooper, C. Global, regional, and national disability-adjusted life-years (DALY) for 359 diseases and injuries and health life expectancy (HALE) for 195 countries and territories, 1990-2017: A systematic analysis for the Global Burden of Disease Study 2017. The Lancet 2018, 392, 1859-1922.

5. $\quad$ la Torre, J.A.-D.; Vilagut, G.; Ronaldson, A.; Serrano-Blanco, A.; Martín, V.; Peters, M.; Valderas, J.M.; Dregan, A.; Alonso, J. Prevalence and variability of current depressive disorder in 27 European countries: A population-based study. Lancet Public Health 2021, 6, e729-e738. [CrossRef]

6. Poeco, D.L. Encuesta Nacional de Salud de España. Available online: https://www.sanidad.gob.es/estadEstudios/estadisticas/ encuestaNacional/encuestaNac2017/ERRORESMUESTREO.pdf (accessed on 5 November 2021).

7. Báez Suárez, A. El Ejercicio Terapéutico Como Tratamiento para la Depresión. Conversation. Available online: https://www. ulpgc.es/noticia/2021/10/07/Ejercicio-terapeutico-como-tratamiento-depresion-Conversation (accessed on 5 November 2021)

8. Caballero Alonso, M.S.; Franco Torres, V.J.; Marchán Cárdenas, J.C.; Montagut Vargas, A.J. Depresión Resistente al Tratamiento: Un Concepto Disgregado y el Más Infortunado Diagnóstico Evolutivo de la Depresión Mayor; Universidad del Norte: Barranquilla, Colombia, 2020.

9. Quintana, D. Programa Comunitario de actividad física para adultos mayores del Consejo Popular Rafaelito. Su efecto en la depresión, bienestar subjetivo y condición física. Lect. Educ. Física Deportes 2021, 26, 280.

10. Matsudo, S.M.M. Recomendaciones de actividad física: Un mensaje para el profesional de la salud. Rev. Nutr. Clín. Metab. 2019, 2, 2. [CrossRef]

11. Caspersen, C.J.; Powell, K.E.; Christenson, G.M. Physical activity, exercise, and physical fitness: Definitions and distinctions for health-related research. Public Health Rep. 1985, 100, 126.

12. Granados, S.H.B.; Cuéllar, Á.M. Influencia del deporte y la actividad física en el estado de salud físico y mental: Una revisión bibliográfica. Katharsis Rev. Cienc. Soc. 2018, 25, 141-160.

13. García, R.J. Universidad de Murcia. Fuerza, su Clasificación y Pruebas de Valoración. 2007. Available online: https://studylib.es/ doc/4568750/fuerza--su-clasificaci\%C3\%B3n-y-pruebas-de-valoraci\%C3\%B3n (accessed on 5 November 2021).

14. González Jurado, J.A. La Actividad Física Orientada a la Promoción de la Salud; Escuela Abierta. Rev. Investig. Educ. 2004, 7, 73-96.

15. Calvó, F.E. PreD: Prevenir Depresión, un Programa de Educación en Salud Mental: Tesis de Maestría en Psicología Clínica y de la Salud y Terapias Cognitivo-Conductuales. Difusiones 2020, 19, 10-28.

16. Rosenbaum, S.; Tiedemann, A.; Sherrington, C.; Curtis, J.; Ward, P. Physical activity interventions for people with mental illness: A systematic review and meta-analysis. J. Sci. Med. Sport 2014, 18, e150. [CrossRef]

17. Firth, J.; Cotter, J.; Elliott, R.; French, P.; Yung, A.R. A systematic review and meta-analysis of exercise interventions in schizophrenia patients. Psychol. Med. 2015, 45, 1343-1361. [CrossRef]

18. Gómez-Juanes, R.; Roca, M.; Gili, M.; García-Campayo, J.; García-Toro, M. Estilo de vida saludable: Un factor de protección minusvalorado frente a la depresión. Psiquiatr. Biol. 2017, 24, 97-105. [CrossRef]

19. González, I.; Gómez, N.; Ortiz, R.; Ibarra, V. Ejercicio físico como tratamiento adyuvante de los trastornos mentales. Una revisión narrativa. An. Fac. Cienc. Méd. 2018, 3, 27-32. [CrossRef]

20. Bellón, J.A.; Conejo-Cerón, S.; Rodríguez-Bayón, A.; Ballesta-Rodríguez, M.I.; Mendive, J.M.; Moreno-Peral, P.J.G.S. Enfermedades mentales comunes en atención primaria: Dificultades diagnósticas y terapéuticas, y nuevos retos en predicción y prevención. Gac. Sanit. 2020, 34, 20-26. [CrossRef]

21. Vancampfort, D.; Stanton, R.; Probst, M.; De Hert, M.; Van Winkel, R.; Myin-Germeys, I.; Kinyanda, E.; Mugisha, J. A quantitative assessment of the views of mental health professionals on exercise for people with mental illness: Perspectives from a low-resource setting. Afr. Health Sci. 2019, 19, 2172-2182. [CrossRef]

22. Pickett, K.; Kendrick, T.; Yardley, L. "A forward movement into life": A qualitative study of how, why and when physical activity may benefit depression. Ment. Health Phys. Act. 2017, 12, 100-109. [CrossRef]

23. Kennedy, S.H.; Raymond, W.L.; McIntyre, R.S.; Tourjman, S.V.; Bhat, V.; Blier, P.; Hasnain, M.; Jollant, F.; Levitt, A.J.; MacQueen, G.M.; et al. Canadian Network for Mood and Anxiety Treatments (CANMAT) 2016 clinical guidelines for the management of adults with major depressive disorder: Section 3. Pharmacological treatments. Can. J. Psychiatry 2016, 61, 540-560. [CrossRef]

24. Farioli Vecchioli, S.; Sacchetti, S.; Di Robilant, N.V.; Cutuli, D. The Role of Physical Exercise and Omega-3 Fatty Acids in Depressive Illness in the Elderly. Curr. Neuropharmacol. 2018, 16, 308-326. [CrossRef]

25. Julcarima De la Cruz, R.B.; Horna Abanto, A.E. La Efectividad del Ejercicio Para el Tratamiento de la Depresión en los Pacientes Adultos Mayores. 2018. Available online: http://repositorio.uwiener.edu.pe/handle/123456789/2598 (accessed on 5 November 2021). 
26. Alomoto Mera, M.; Calero Morales, S.; Vaca García, M.R. Intervención con actividad físico-recreativa para la ansiedad y la depresión en el adulto mayor. Rev. Cuba. Investig. Biomed. 2018, 37, 47-56. Available online: http://scielo.sld.cu/scielo.php? script=sci_arttext\&pid=S0864-03002018000100005 (accessed on 5 November 2021).

27. López, R.N.A.; Rodríguez, S.P.; Rodríguez, R.P. El Ejercicio Físico Como Tratamiento Eficaz Para La Depresión Y Sus Beneficios. Libro De Actas, IV Congreso Internacional de Deporte Inclusivo, Universidad de Almería. 2017. Available online: https: / / www.researchgate.net/publication/310604889 (accessed on 5 November 2021).

28. Perez-Sousa, M.A.; Olivares, P.R.; González-Guerrero, J.L.; Gusi, N. Effects of an exercise program linked to primary care on depression in elderly: Fitness as mediator of the improvement. Qual. Life Res. 2020, 29, 1239-1246. [CrossRef]

29. Vancampfort, D.; Rosenbaum, S.; Schuch, F.; Ward, P.; Richards, J.; Mugisha, J.; Probst, M.; Stubbs, B. Cardiorespiratory Fitness in Severe Mental Illness: A Systematic Review and Meta-analysis. Sports Med. 2016, 47, 343-352. [CrossRef]

30. Gordon, B.R.; McDowell, C.P.; Hallgren, M.; Meyer, J.D.; Lyons, M.; Herring, M.P. Association of efficacy of resistance exercise training with depressive symptoms: Meta-analysis and meta-regression analysis of randomized clinical trials. JAMA Psychiatry 2018, 75, 566-576. [CrossRef]

31. Pastor, I.G.; Rico, J.A.Q.; Pastor, A.G.; García, R.N.; Munuera, M.C.C. Depresión, ansiedad y salud autopercibida en estudiantes de Medicina: Un estudio transversal. Rev. Española Educ. Méd. 2021, 2, 21-31. [CrossRef]

32. Garcia Moreno, K.M. Depresión y Factores Antropometricos en Adulto Mayor, Estudio de Costos de la Obesidad: Análisis de la Encuesta de Demografía y Salud Familiar 2018. Ph.D. Thesis, Universidad Ricardo Palma, Santiago de Surco, Peru, 2020.

33. Calderón, D.J. Epidemiología de la depresión en el adulto mayor. Rev. Med. Herediana 2018, 29, 182-191. [CrossRef]

34. Portellano-Ortiz, C.; Garre-Olmo, J.; Calvó-Perxas, L.; Conde-Sala, J.L. Depresión y variables asociadas en personas mayores de 50 años en España. Estadísticas 2018, 11, 216-226. [CrossRef]

35. Mera, M.A.; Morales, S.C.; García, M.R. Intervention with physical-recreational activity to anxiety and depression in the elderly. Rev. Cuba. Investig. Bioméd. 2018, 37, 47-56.

36. Couto Núñez, D.; Nápoles Méndez, D. Aspectos sociopsicológicos del climaterio y la menopausia. Medisan 2014, 18, 1409-1418 Available online: http:/ / scielo.sld.cu/scielo.php?script=sci_arttext\&pid=S1029-30192014001000011 (accessed on 5 November 2021).

37. Valiensi, S.M.; Starvaggi, A.; Folgueira, A.; Izbizky, G.; Pilnik, S.; Belardo, M. Sleep quality and related factors in postmenopausal women. Maturitas 2019, 123, 73-77. [CrossRef]

38. Campo Barrientos, P.D. Perfil Epidemiológico de los Consumidores de Antidepresivos en España, ens 2014. 2016. Available online: https: / / eprints.ucm.es/id/eprint/51082/ (accessed on 5 November 2021).

39. Gil-García, E.; Matos, R.C.; Claudel, B.N.; Zambrano, A.G.; Vázquez-Santiago, S.; León, A.C.; Avilés, N.R. Consumo de psicofármacos en Andalucía. Un análisis de la Encuesta Andaluza de Salud desde la perspectiva de género. Rev. Española Drogodepend. 2020, 45, 52-68.

40. González, N.F.; Rivas, A.D. Actividad física y ejercicio en la mujer. Rev. Colomb. Cardiol. 2018, 25, 125-131. [CrossRef]

41. García, C.M.; González-Jurado, J.A. Impacto de la inactividad física en la mortalidad y los costos económicos por defunciones cardiovasculares: Evidencia desde Argentina. Rev. Panam. Salud Pública 2017, 41, e92. [CrossRef] [PubMed]

42. Bustos, L. Entre el rosa y el azul: Desafíos de la expresión de género en las clases de Educación Física. Available online: https:/ / www.memoria.fahce.unlp.edu.ar/trab_eventos/ev.12919/ev.12919.pdf/ (accessed on 1 November 2021).

43. Ramírez Pérez, P. Sedentarismo, Factor de Riesgo o Protección Ante la Depresión? Universidad de Cádiz: Cádiz, Spain, 2019; Available online: https:/ / rodin.uca.es/handle/10498/21582 (accessed on 15 November 2021).

44. Almagro Valverde, S.; Guzmán, D.; Tercedor Sánchez, P. Actividad física y depresión: Revisiónsistemática/Physical activity and depression: A systematic review. Rev. Int. Med. Cienc. Act. Física Deporte 2014, 14, 377-392. Available online: Http: / / cdeporte.rediris.es/revista/revista54/artactividad472.htm (accessed on 5 November 2021).

45. Cornejo Callejo, P. El uso del Ejercicio Físico Como Intervención Enfermera en Pacientes con Depresión Leve y Moderada; Universidad de Cantabria: Santander, Spain, 2017; Available online: https://repositorio.unican.es/xmlui/handle/10902/11631 (accessed on 5 November 2021).

46. Paucara Pfoccori, M. Inactividad física Asociado a Depresión y Ansiedad en Pacientes con Enfermedades Cardiovasculares que Asisten a Consulta Externa de Cardiología del Hospital III Goyeneche, febrero 2020; Universidad Nacional de San Agustín de Arequipa: Arequipa, Peru, 2020; Available online: http:/ / repositorio.unsa.edu.pe/handle/UNSA/11139 (accessed on 5 November 2021).

47. Guevara Moreno, A. Coaching y Ejercicio Físico: Optimización de Resultados en Pacientes con Depresión. Una Revisión Sistemática; Universidad de Almería: Almeria, Spain, 2020; Available online: http:/ / repositorio.ual.es/handle/10835/10176 (accessed on 5 November 2021).

48. Lafuente Vayá, A.J. Revisión de la Epidemiología Depresiva. Propuesta de Programa de Actividad Física en Población con Trastorno Depresivo Mayor Para Prevenir la Disminución del Volumen Hipocampal; Universidad de Valencia: Valencia, Spain, 2020; Available online: https:/ / riucv.ucv.es/handle/20.500.12466/1716 (accessed on 5 November 2021).

49. Dao, A.T.M.; Nguyen, V.T.; Nguyen, H.V.; Nguyen, L.T.K. Factors Associated with Depression among the Elderly Living in Urban Vietnam. Biomed Res. Int. 2018, 2018, 2370284. [CrossRef] [PubMed]

50. Arias de la Torre, J. Influencia de la Situación Laboral y Otros Factores Socioeconómicos Sobre la Salud Mental de la Población Española= Influence of the Employment Status and other Socio-Economic Factors on the Mental Health of the Spanish. Ph.D. Dissertation, Universidad de León, León, Spain, 2019. Available online: https://buleria.unileon.es/handle/10612/10738 (accessed on 5 November 2021). 